\title{
Bienvenidos a Canadá? Globalization and the Migration Industry Surrounding Temporary Agricultural Migration in Canada
}

\author{
Jenna L. Hennebry \\ Wilfrid Laurier University \\ jhennebry@wlu.ca
}

\begin{abstract}
"Migrant workers" have become an important resource in the global economy, and not solely for employers and governments. Multilateral agreements, trade liberalization, and advancements in communication and transportation have enabled flows of the world's poor into international labour migration systems, often mediated by a migration industry that profits from providing services to employers and migrants. Based on ethnographic case studies in Mexico, participant observation in Ontario, and interviews with migrant workers and their families, farmers, government representatives and other intermediaries, this paper examines the extent to which a migration industry has formed around the Mexican-Canadian Seasonal Agricultural Worker Program.
\end{abstract}

Keywords: temporary labour migration, seasonal agricultural worker, globalization, migration industry

\section{Résumé}

Les "travailleurs migrants" sont devenus une source importante de main d'œuvre dans l'économie globale, et pas seulement pour les employeurs et les gouvernements. Les accords multilatéraux, la libéralisation des échanges, et les progrès accomplis dans les sphères de la communication et des transports on rendu possible l'épanchement des pauvres du monde entier dans les systèmes internationaux de migration de main d'œuvre, souvent négocié par une industrie de migration qui profite d'offrir des services auprès des employeurs et des migrants. Basé sur une étude de cas ethnographique au Mexique, une observation participante en Ontario, et des entrevues de travailleurs migrants et de leurs familles, d'agriculteurs, de représentants gouvernementaux et d'autres intermédiaires, cet article examine l'étendue de l'industrie de migration qui s'est formée autour du Programme des travailleurs agricoles saisonniers mexico-canadien.

Mots-clés: migration de main d'œuvre temporaire, travailleur agricole saisonnier, globalisation, industrie de migration 


\section{Introduction}

Multilateral government agreements, trade liberalization, and advancements in communication and transportation networks have enabled flows of the world's poor into managed labour migration programs (Martin and Martin, 2001; Massey et al., 1998; Stalker, 2000; Parreñas, 2001). These advancements have also facilitated the increasing role of private actors in the migration process. In particular, temporary migration is increasingly mediated by a growing migration industry that targets both migrants and employers, providing a host of services ranging from recruitment and mediation between employers and governments, to remittance-sending services offered to migrants and their families.

This research examines a case study of the Seasonal Agricultural Worker Program, SAWP), which is the longest standing temporary foreign worker program in Canada, operating for forty years governed by bilateral agreements with the Caribbean (1966), and Mexico (1974). Following a migration systems theory approach to the political economy of temporary migration (Boyd and Greico, 1998; Fawcett, 1989; Massey et al., 1993; Zlotnik, 1998), this research adopts an understanding of SAWP migrant workers as transnational actors and emblematic subjects of the spatiotemporal realities of contemporary economic globalization. A significant focus of this research has been to uncover the extent to which a "migration industry" has formed around this program (and to uncover who else stands to profit from this temporary migration system), and to explore the "mesostructures" of the SAWP, which typically form around migration networks (Castles and Miller, 2003). This research investigates the role of these mesostructures and intermediaries, and considers the significance of globalization, and its constituent advancements in communication, for temporary migration through the Mexican-Canadian SAWP.

Adopting Urry's “mobile sociology" approach (2000), data have been gathered at multiple locales from three units of analysis: the migrant worker in Canada, the family of migrant workers in Mexico, and the migration networks and institutional frameworks that facilitate these flows. Findings are based on data that was collected between 2002-2005 through 5 ethnographic case studies in Mexico, 450 hours of participant observation on Ontario farms, semistructured interviews with 25 migrant workers, 10 farmers and representatives from other state and nonstate intermediaries, 35 migrant families and 15 spouses of migrant workers in Mexico, and on secondary data from Citizenship and Immigration Canada (CIC) and Human Resources and Social Development Canada (HRSDC), and El programa de trabajadores agrícolas temporales México-Canadá (PTAT).

\section{Theorizing Globalization, ICTs and Temporary Migration}

The literature on globalization, and the majority of research on international migration in Canada, does not extensively address temporary migration. Globalization 
literature, although voluminous, has not led to a clear consensus as to what the concept means (e.g., Bartleson, 2000; Harvey, 1990; Therborn, 2000); and temporary migration is often neglected. Canadian migration research also tends to neglect temporary migration, focusing on such issues as permanent migration, settlement, integration, social cohesion, and security (see: www.metropolis.net). Many claim that, with globalization, there are increased social linkages (networks) across large distances (i.e., increased flow across time and space). Harvey (1990) has described a process by which time and space are not given and absolute, but are increasingly "compressed" by new transportation and communication technologies. These have the effects of unifying space and eliminating many of the characteristics of place. Arguably, through these advancements, temporary migration networks have been made more extensive and robust. As Urry claims, "networks have to be performed" and these networks involve combinations of mobilities and highly structured material immobilities (2000:109). This is particularly true for temporary migration networks, where significant modes of transnational practice (e.g., remittance sending) enable migrants to engage and maintain networks, maintain family ties and responsibilities, strengthen community networks, and organize social and economic development (Vertovec, 2004). As a characteristic of globalization, the expansion of Information and Communication Technologies (ICTs) has a direct relationship to how people move across and imagine time and space. For example, new mechanisms for sending money home electronically allow migrants to participate in their household economies from afar through remittance sending services (Alarcón and Hinojosa-Ojeda, 1998). Some see a direct relationship between advancements in ICTs and expansions in migration flows. Castles and Miller (2003) contend that, with globalization, improvements in transportation and communication mean the rapidly increasing mobility of people across national borders. Stalker (2000) claims that falling prices for transportation and the increased speed of communication have changed the character of international migration, making it much less permanent. Arguably, these developments have more impact on temporary migration in particular.

Much of the attention paid to the role of ICTs in globalization and migration has centred on transnational communities (Vertovec, 2004; Castells, 1996); and transnational social movements, such as Mexican Hometown Associations (Alarcón, 2000; Orozco, 2003, Portes, 1998), which utilize ICTs to contest the new economic and social relations of globalization. Portes (1998) in particular, contends that transnationalism and the use of ICTs may lead to political empowerment, resisting and contesting domination, and the creation of new forms of cultural expression. However, Castells (1996) argues that in the contemporary network society, ICTs are particularly important, not just with respect to resistance, but in terms of the organization of social and political power. Network society refers to a network of communications, defined by hubs where these networks crisscross, and real power is negotiated within the networks (Castells, 1996:21, 446). In the network society, 
a fundamental form of social domination is the prevalence of the "space of flows" inducing a social/territorial exclusion which bypasses and marginalizes people and places (Fawcett, 1989). For research on temporary migration, the network society conceptualized by Castells (1996) is especially relevant: it reorganizes space and place so that power relations are negotiated in new territorial and social parameters. Thus, the ability to traverse these new territorial and social parameters with ease (i.e., to be mobile) is particularly important in the entrenchment of global stratification as redefined within globalization. Clearly, access to and use of ICTs are significant to one's position in global power relations. However, it is unclear whether the use of ICTs among temporary migrant communities facilitates empowerment and resistance or furthers exploitation and dependency. In fact, research has not focused on the role of ICTs in the SAWP, and very little has examined the role of ICTs as a component of globalization in temporary migration systems more broadly. Though there is some research on globalization and the SAWP (e.g., Basok, 2003; Binford, 2002; Colby, 1997; Preibisch, 2007a; Smart, 1997) it has yet to examine the role of communications technologies, the costs and methods of remittance transfers which inevitably impact migrants' household economies, the role of remittances in development, or the role of intermediaries (e.g., third party recruiters, hometown associations) in the temporary migration of SAWP workers.

\section{Temporary Migration: Trends and Policies}

In the post-Cold War era there has been an expansion of what Castles and Miller (2003:102) refer to as "the second generation" of temporary foreign worker programs in Europe and North America, with seasonal agricultural migrations increasing annually (Held et al., 1999:301). For example, in 1999, Italy admitted 20,000 seasonal migrant workers in the country, which is a tenfold increase since 1992 (Castles and Miller, 2003:101; OECD, 2001:195). In a world economy characterized by local specializations, the emergence of a global labour market is encouraging labour specialization, with some countries specializing in particular types of workers (Harris, 1995:2). For example, the majority of Mexican labour migrants in the United States and Canada are concentrated in the agricultural sector (Griffith, 2004). In addition, nation states in Europe and North America have moved towards adopting managed seasonal agricultural migration programs, such as the Canadian SAWP.

Stalker (2000) estimates 120 million people are working outside their country of birth, excluding those who have emigrated "permanently" to other countries. According to the OECD, the flow of foreign workers into Canada was 99.1 thousand in 2005. Canada has the fourth largest inflow of foreign workers, following after the United States, Germany, and Japan; the number of foreign workers in Canada from 1995-2005 has surpassed the numbers of foreign workers in the United Kingdom 
and many other selected European countries (Lowell, 2007). In Canada, there has been an increasing emphasis on the recruitment of temporary migrant workers since changes to the IRPA came into force in 2002, with a notable shift toward prioritizing the "flexibility" and "labour force responsiveness" of Canadian immigration policy, and an increased emphasis on the recruitment of noncitizen, temporary workers. The more recent changes to the foreign worker program (CIC, 2007b) and the introduction of Bill C-50 furthers this trend toward the labour force responsiveness of Canadian immigration policy, and provides the Minister of Citizenship and Immigration significant discretionary powers to select immigrants and temporary migrants on the basis of labour force needs and job availability.

In $1973,57 \%$ of all people classified as "workers" entered the Canadian workforce with permanent resident status; by 1993 , only $30 \%$ of workers were permanent immigrants, while $70 \%$ came in as migrant workers on temporary employment authorizations (Sharma, 2001:424). Currently, temporary employment authorizations are on average larger than the number of landed immigrants entering the labour force annually (Ruddick, 2000). Table 1 shows the flow statistics for foreign workers and other temporary residents from 2003-2006. In 1980, only 58,728 foreign workers entered the country, and by 1990 the flow peaked for that decade at 85,407. Since then, entries of temporary migrants, and specifically foreign workers, have stayed high. In 2004, there were 95,223 foreign workers, 15,881 seasonal re-entries, and a total of 244,344 temporary residents flowing into Canada, excluding dependants and those with Minister's permits. The annual flow of temporary foreign workers into

Table 1: Canada - Annual Flow* of Temporary Residents by Primary Status 2003-2006

\begin{tabular}{|c|c|c|c|c|}
\hline Primary status & 2003 & 2004 & 2005 & 2006 \\
\hline & \multicolumn{4}{|c|}{ Number } \\
\hline Initial entries & 73,704 & 79,342 & 85,905 & 95,277 \\
\hline Seasonal re-entries & 14,800 & 15,881 & 16,703 & 17,381 \\
\hline Foreign workers & 88,504 & 95,223 & 102,608 & 112,658 \\
\hline Foreign students & 57,583 & 54,654 & 56,674 & 61,703 \\
\hline Adult refugee claimants & 23,248 & 18,958 & 14,667 & 16,525 \\
\hline Other refugee claimants & 6,917 & 5,240 & 3,890 & 4,610 \\
\hline Refugee claimants & 30,165 & 24,198 & 18,557 & 21,135 \\
\hline Other humanitarian cases & 442 & 419 & 346 & 245 \\
\hline Humanitarian population & 30,607 & 24,617 & 18,903 & 21,380 \\
\hline Other & 66,628 & 69,850 & 68,512 & 72,315 \\
\hline Total & 243,322 & 244,344 & 246,697 & 268,056 \\
\hline
\end{tabular}

Source: CIC, 2007

Note: This represents the number of temporary residents identified as entering the CIC system (and presumably the country) for the first time. CIC commonly measures the annual flow of foreign workers, foreign students and the humanitarian component of the temporary resident population. Flows are calculated as of the earliest effective date of any valid permit issued to a temporary resident. Seasonal workers are counted each time they re-enter the system. 
the country now exceeds 100,000 per year, with over 112,000 individuals entering Canada as temporary foreign workers in 2006 (CIC, 2007a). This is up from some 80,000 only a decade earlier and double the number arriving in 1980. Between 1991 and 2003, 2,063,022 temporary migrant workers reached Canada, including 443,799 in 2001-03 alone (Hawthorne, 2008). Foreign workers have originated from a number of countries, with the largest inflows originating in the United States, Philippines, and Mexico (See Table 2).

There has also been a significant rise in the numbers of foreign workers entering Canada through the SAWP. In 1966, only 264 Mexican workers came to work on Canadian farms through the SAWP, and by 2002 the number increased to 10,739 , and over the last ten years, the number of SAWP participants has doubled (CIC, 2005; FARMS, 2005). In 2006, the total number of vacancies filled in Ontario was 17,786 on nearly 1,500 farms (Foreign Agricultural Resource Management Services [FARMS], 2007). Ontario employs the majority of these workers in agricultural sectors including tobacco, vegetables, fruit, greenhouses, and tree farming (FARMS, 2005). Following Ontario, Quebec employed a significant number of migrant workers $(5,217)$ in 2007: 3,037 Mexican and 165 Caribbean workers through the SAWP and 2,015 Guatemalan workers through the Foreign Worker Program (Fondation des entreprises en recrutement de la main-d'oeuvre agricole étrangère [FERME], 2007). This is a significant increase since 2000 when only 1,611 migrant workers came to work on Quebec farms. There has been a rapid growth in the number of Guatemalan

Table 2. December 1st Stock of Foreign Workers by Top Source Countries, 1998-2006

\begin{tabular}{lrrrrrrrrr}
\hline \multirow{1}{*}{ Source Countries } & 1998 & 1999 & 2000 & 2001 & 2002 & 2003 & 2004 & 2005 & 2006 \\
\cline { 2 - 9 } United States & \multicolumn{7}{c}{ Number } \\
Philippines & 20,297 & 19,821 & 20,929 & 20,721 & 20,139 & 20,657 & 21,649 & 23,288 & 24,830 \\
Mexico & 5,860 & 5,969 & 6,345 & 8,244 & 10,637 & 12,512 & 15,312 & 17,739 & 21,623 \\
United & 6,742 & 8,085 & 9,959 & 11,121 & 11,588 & 11,589 & 11,920 & 13,327 & 15,219 \\
Kingdom & 5,110 & 5,586 & 6,306 & 6,829 & 6,920 & 7,299 & 9,232 & 10,492 & 10,879 \\
France & 2,459 & 2,789 & 3,261 & 3,657 & 3,989 & 4,343 & 5,917 & 7,269 & 8,895 \\
Australia & 3,856 & 3,880 & 4,394 & 5,263 & 6,063 & 6,719 & 8,050 & 8,386 & 8,849 \\
Japan & 5,255 & 6,145 & 5,444 & 5,490 & 6,752 & 7,027 & 7,241 & 7,670 & 7,730 \\
India & 1,290 & 1,524 & 1,871 & 1,890 & 2,193 & 2,829 & 3,997 & 5,544 & 7,069 \\
China, People's Republic of & 1,248 & 1,206 & 1,355 & 1,563 & 1,916 & 2,316 & 3,214 & 4,485 & 6,635 \\
Jamaica & 5,125 & 5,457 & 5,216 & 5,664 & 5,449 & 5,942 & 5,997 & 6,201 & 6,502 \\
Germany & 1,583 & 1,613 & 1,944 & 2,211 & 1,970 & 2,204 & 3,046 & 3,548 & 5,292 \\
Trinidad and Tobago & 1,766 & 1,630 & 1,746 & 1,744 & 1,624 & 1,618 & 1,689 & 1,699 & 1,561 \\
Top 10 source countries & 58,053 & 60,975 & 65,669 & 71,090 & 75,700 & 81,233 & 92,529 & 104,401 & 118,231 \\
Other countries & 16,725 & 18,626 & 21,456 & 23,121 & 24,195 & 27,590 & 32,820 & 38,304 & 48,008 \\
Total & 74,778 & 79,601 & 87,125 & 94,211 & 99,895 & 108,823 & 125,349 & 142,705 & 166,239 \\
\hline
\end{tabular}

Source: CIC, 2007

Note: The foreign worker category excludes foreign students who may have been issued a work permit and individuals who have been issued a work permit for humanitarian reasons, such as refugee claimants. 
workers in particular, from 215 migrants in 2003 to 2,015 migrants in 2007. Also, with recent expansions of the program in the western provinces, British Columbia now employs over 2,000 SAWP workers. Table 3 shows the stock of processed participants in the Mexican SAWP across Canada in 2007 at time of data collection (PTAT, 2007).

Table 3. Mexican Seasonal Agricultural Workers in Canada through SAWP by Province and Sex , 2007*

\begin{tabular}{|c|c|c|c|c|}
\hline Province & Females & Males & Total $^{* *}$ & $\%$ \\
\hline Alberta & 110 & 494 & 604 & 4 \\
\hline British Columbia & 33 & 2000 & 2033 & 14 \\
\hline Prince Edward Island & & 72 & 72 & 1 \\
\hline Manitoba & & 283 & 283 & 2 \\
\hline New Brunswick & & 6 & 6 & 0 \\
\hline Nova Scotia & 4 & 38 & 42 & 0 \\
\hline Ontario & 330 & 7797 & 8129 & 57 \\
\hline Quebec & 65 & 2936 & 3001 & 21 \\
\hline Saskatchewan & 21 & 51 & 72 & 1 \\
\hline Total & 563 & 13677 & 14242 & $100 \%$ \\
\hline \multicolumn{5}{|c|}{ Source: PTAT, Mexico, requested estimates, 2007} \\
\hline \multicolumn{5}{|c|}{ Note: * ${ }^{*}$ Counts reflect stock of processed applicants at time of data collection, not the total count for 2007.} \\
\hline
\end{tabular}

\section{Mesostructures, Intermediaries and the Formation of a Migra- tion Industry}

Mesostructures, according to Castles and Miller (2003), tend to form around migration networks, and may have a significant role in temporary migration systems. According to Castles and Miller (2003), within these mesostructures certain individuals, groups, or institutions may take on the role of mediating between migrants, their employers, and political/economic institutions, often profiting from this role. These actors may also mediate between migrants and their families and communities in Mexico. The following section examines the extent to which a "migration industry" (Castles and Miller, 2003:28) has been emerging around the SAWP, which typically consists of recruitment organizations, lawyers, agents, smugglers, and other intermediaries (Harris, 1995:132-6).

\section{SAWP Mesostructure}

The Mexican-Canadian SAWP is a government-to-government program of managed migration (Aceytuno and Greenhill, 1999), involving both public and private sectors in Canada and the labour supply countries. Workers enter their employment 
under the Agreement of the Employment in Canada of Seasonal Agricultural Workers from Mexico, which is a four-party agreement between the worker, the employer, the Government of Mexico, and the Government of Canada (FARMS, 2005; 2007). The Mexican government manages a substantial portion of the administrative work, involving recruitment of workers in Mexico through La Secretaría del Trabajo y Previsión Social (STPS), and worker representation in Canada through the Mexican Consulate (mainly in Toronto and recently in Leamington). The Secretaría de Relaciones Exteriores or SRE, (The Ministry of Foreign Affairs) coordinates the M/ SAWP (in Mexico, the PTAT) with the Mexican Consulate, and the Secretaría de Salud (The Ministry of Health) performs the required medical examinations in Mexico and issues a medical approval. The Canadian and Mexican governments jointly manage the program, with the SRE and STPS selecting workers from Mexico and the Canadian government vetting employers. In Canada, HRSDC evaluates employer requests for workers, and issues labour market opinions, and CIC provides the appropriate documentation to workers and employers for border crossing and employment regulations, which are then subject to Canadian Border Services Agency (CBSA) approval. In Ontario, Foreign Agricultural Resources Management Services (FARMS) manages the day-to-day administration of the program. FARMS is a nonprofit private sector organization that was federally incorporated in 1987, and is governed by a Board of Directors appointed from commodity groups participating in the program. In 2007-2008, although it is not mandatory, all farm employers in Ontario (approximately 1,600) hired workers through FARMS.

To FARMS, the growers' association consortium, employers also pay administration fees (\$35 per worker + GST) which they can partly recover from workers. FARMS receives no direct government support, but is funded exclusively from the fees collected from employers when their seasonal worker requests are approved for processing (FARMS, 2005:1). Once migrants arrive, employers determine the duration of stay, the type of work, and whether workers will be selected to come back to the program; they can request up to six named workers to return for the next season on their farm. Comments from an interview with a grower best illustrate this process:

First we go to the division of HRSDC [FARMS], which is a privately run farm labour pool and put in a "Canadians First" application. We describe the hours and the type of work. An ad is run for a month, and we don't glaze it over either. We say how tough the work is. Then we put the order in and apply for Mexicans. Then you go through the FARMS and Mexican consulate. (Farmer 6, 2005:2)

Canadian Agricultural Travel Limited (CanAg Travel), the government authorized travel agent, manages the air and ground transportation for workers internationally and within Canada (FARMS, 2005). FARMS requires all travel arrangements be booked through this company, which means that the profits of flight sales go to one travel agency and flight provider. This frustrates employers and workers since 
prices are negotiated between FARMS and the two authorized carriers (Air Canada or Mexicana Airlines) and fixed at rates that are often higher than comparable flight costs outside the program. For example:

CanAg Travel? There is no other option. I think it may be more costly. One year, one of the worker's mother passed away and we wanted to send him home and have him come back after the funeral. It was kinda frustrating since the price with CanAg travel was twice as much as Air Canada online. There was no other option. (Farmer 6, 2005:4)

The shared involvement by the Canadian and Mexican governments distinguishes the SAWP from the agricultural guest worker program in the United States (the H2A Program) which is controlled and managed mostly by private agents who control recruitment in response to American labour demands on behalf of American employers (Griffith, 2004). In Canada, private agents are more indirectly connected to workers, and directly connected to employers. However, the organization of the SAWP institutionalizes power relations in such a way that migrant workers are controlled and restricted temporally and spatially from the moment they enter the evaluative process of the program, and this makes these migrants a "captive market" for intermediaries and businesses targeting migrants. Government, SAWP management, FARMS, and employers are the most powerful actors in the program, as they have direct control over the spatial and temporal parameters of workers' lives. There are also a number of intermediaries who do not necessarily act in the interests of workers, such as remittance-sending service providers, but provide a service to workers that may directly affect their participation in the program. Others may serve a mediating function, such as coyotes or SAWP middlemen. There are very few parties representing the interests of workers, who do not directly profit from their involvement. Those groups who do represent the interests of workers are out of reach for many workers and, although they have a direct impact on workers' lives, they are not officially connected to the program (e.g., NGOs and advocacy groups). The group with the most significant involvement, the United Food and Commercial Workers Union (UFCW), has advocated for workers' rights to unionize and for recognition under the Ontario Health and Safety Act, has established migrant resource centres across Ontario (and in other provinces as well), and has launched legal challenges on behalf of workers (Preibisch, 2007b).

\section{Kinship Networks and other Intermediaries}

As was shown in the previous section, although the bilateral agreement framework involves the state in the recruitment of Mexican workers, recruiting and managing labour migration is often mediated for employers and governments by private actors and organizations, such as FARMS, that glean significant benefits from the employment of migrant labour. The entry of most migrant labourers into the SAWP is also 
mediated, but typically by a family member, and in some cases by a private actor paid for the service. From the case study ethnography and the qualitative interviews, it is clear that entrance into the SAWP is typically facilitated or assisted by other family members. In each of the 4 case studies, the worker became aware of the program through a family member. In 19 interviews, workers claimed that family members provided information on and transportation to the STPS office where the SAWP is administered in Mexico City, acting as mediators between individuals and the migration system. For example:

My brother told me about it. One day we went to the office together in Mexico and he showed me how I could apply. (Worker 13, FARM 1:5)

My father always told me I could go when I was old enough. (Worker 7, FARM 1:6)

My cousin and some of the other men in our town have always gone to Canada. I did not plan to go, but things changed and now I have to. We need the money. That was 5 years ago now. (Worker 19, FARM 1:6)

Other workers also indicated that, in addition to family members, there were other individuals and groups that facilitated entry into the program. Six workers indicated that they knew of or had contacted a lawyer to assist them in gaining entry into the program. Four workers claimed that an individual had visited their community offering to "help" people get into the program. For example:

He asked me if I was interested in joining the program to go to Canada. He told me that, for 1000 Pesos, he could help me get in. (Worker 21, FARM 3:4)

Yeah, there is this guy who you can get to help you. You can pay him to get in. I think he works for the PTAT. (Worker 12, FARM 5:5)

According to these workers, for a fee (approximately 1000 pesos) a man passed through their communities and offered to show people how to navigate the SAWP, "guaranteeing" entry for another 1000 pesos. In addition to these workers, in two of the four case study areas migrant families indicated that they were aware of an individual that could help "get them into the program" for a fee. In Mexico, family members and friends of the workers mentioned that they faced difficulty getting into the program and that "it helps if you can pay someone to get you in, like paying the coyotes to get you into the US" (Fieldnotes, December, 2003:10-12). In December 2005 , five additional workers indicated that there are individuals who can get you an interview at the PTAT office in Mexico City for a fee of between 1000-2000 pesos.

\section{Third-party Recruiters and Private Intermediaries}

Canada's Foreign Worker Program (FWP), and the SAWP both allow for a role for third-party recruiters, employment agencies, and private intermediaries in locating migrant workers for employers and setting up their contracts for a fee. In the SAWP, 
the role of third-party recruiters is more restricted since the bilateral management of the program involves sending and receiving states in the process of recruitment and job placement. However, as noted previously, a private organization made up of growers' association representatives (FARMS) acts as a third-party agent mediating this process for employers in Canada. In addition, with the expansion of the FWP into low-skill sectors including agriculture, Canada has opened the door for involvement of additional third-party agents and private (for profit) organizations that can assist growers in finding a foreign worker outside of SAWP bilateral agreements. In fact, Canada now hosts thousands of employment agencies, making it easier for employers to "order workers" and involving additional private interests. Third-party recruiters provide a host of services to potential employers including mediating with government and consulate officials to procure visas, often at significant costs (e.g., www. canadaworkpermit.com, www.canadaworkvisa.ca). WorkVantage claims to "cover the whole foreign worker staffing process" which includes identifying particular company requirements, "deal[ing] with Service Canada to get their approval for you to hire foreign workers for your company" and representing foreign workers before the Canadian Consulate in order to get their visas (www.workvantage.com, 2008).

Third-party recruiters are not unique to Ontario or to Canada. In fact, most recruiters have a significant international and transnational presence, and mediate the temporary migration process almost entirely through the unregulated environment of the Internet. Operating in this global space, businesses such as "WorkVantage. ca" and "Workpermit.com" are not regulated at the federal level in Canada, nor in most provinces, such as in Ontario, where most migrant workers are employed. Interestingly, the proliferation of third-party recruiters or mediators has largely been facilitated by improvements in the technologies and systems of transportation and communication, which also allow migrants to maintain closer links with areas of origin. Now, even the initial process of becoming a migrant can be facilitated through ICTs such as the cellular telephone and the Internet. These developments also facilitate the growth of circulatory mobility (and, I contend, play an important role in the contemporary expansion of temporary migration systems), in which people migrate regularly between a number of places where they have economic, social, or cultural linkages (Castles and Miller, 2003:29). The following section examines this important aspect of the migration industry supporting the temporary agricultural migration system between Mexico and Canada.

\section{A Segment of the Growing Migration Industry: Communication and Remittance Services}

One of the most significant components of the migration industry developing around the SAWP is the growth of international ICTs and services such as international tele- 
phone providers and remittance-sending services. Not only does this growth facilitate the proliferation of third-party recruiters as mediating agents of migration, but it also enables temporary seasonal migrants to communicate and send money home regularly. Arguably, transnational communication and the use of ICTs are essential to temporary migration, and seasonal migrants are likely engage in transnational practices to a greater extent than permanent migrants by their very nature as "temporary."

People engage in temporary labour migration as a form of income diversification that supplements the family income and ultimately allows the individual to return home. Families involved in the SAWP organize their finances around remittances, which are earmarked for everything from basic needs, debt repayment, to infrastructural and community development. However, there are also costs, and new and extensive forms of work involved in receiving, managing, and allocating remittances; international telephone calling; and international travel: all necessary components of temporary labour migration which diminish the net earnings of migrants. In addition, temporary migrants represent a new market to providers that is essentially captive, and requires these services in order to facilitate their temporary migration.

Remittance sending is frequent and integral to SAWP participants' family economies. In fact, 23 out of 25 of the workers interviewed indicated that they sent money home monthly and that their family used this money for daily living costs. All migrant families consulted in Mexico see it as the primary purpose of temporary migration. For example:

Of course I send money home. I am here to work and then send money home. That is why I am here ... just to work and send money. It is a sacrifice. (Worker 9, FARM 1:15)

I'm working here because what I make back in Mexico is not enough to support my family. Yes, I send them some every month or ... every two weeks. (Worker 17, FARM 5: 4)

Yes, I come here to work so I can send money home. It is for my life, for my family, and to pay my debts, and therefore yes, it is difficult, but I have to. (Worker 24, FARM 5: 4)

Although each of the migrant workers interviewed indicated that they used remittance-sending and international telephone calling services, they all indicated that there were few options for these very costly services. For SAWP workers, wiring money through a bank can range in cost from $\$ 30-\$ 40$ dollars per transfer, plus exchange fees. All 25 of the SAWP workers interviewed for this research used banks and/or Western Union to send money home during the season). SAWP workers spend a high percentage of their remittances in the form of fixed, pretransfer fees because they tend to remit frequently and send small amounts in each transfer. According to Suro (2003), Latin Americans spend an average of \$200 on remittances sent seven times per year. This average is likely higher for SAWP migrants, since workers are typically paid every two weeks, and they tend to send money after each pay cheque. Table 4 provides estimations of remittance-sending costs to Mexico from Canada. 
Table 4. Estimated Costs of Sending Remittances from Canada to Mexico, 2005*

\begin{tabular}{lc}
\hline \multicolumn{1}{c}{ Institution } & Estimated Cost $^{* *}$ \\
\hline \hline Bank (as wire service) & $\$ 30-45$ \\
Western Union & $\$ 35$ \\
Other money sending service providers & $\$ 20-25$ \\
Money Order & $\$ 40-50$ \\
\hline \hline
\end{tabular}

Note: *Estimations based on interviews with migrant workers, and quotes from service providers.

${ }^{\star \star}$ Estimations based on remittances of under $\$ 1,000.00$.

In the United States, competition for the Latin American remittance market has allowed a number of smaller companies such as Vigo and DolEx to emerge, providing lower fees per remittance for migrants compared to the larger MoneyGram and Western Union companies. The competitive industry in the US means that service providers are more likely to reduce sending costs and provide more "migrantfriendly" services. In fact, in an attempt to capture the remittance market, Citigroup acquired Banamex, Mexico's largest bank, and subsequently revealed new products and services aimed specifically at Latinos in the US. Remittances can now be sent from any Citibank to a Banamex branch for $\$ 10$, and there is an Internet transfer service as well. A spokesman for Citigroup said that they wanted to treat Mexicans in Mexico and Mexicans in the US as a "single entity for marketing purposes." He described this market as worth $\$ 1$ trillion, divided roughly 60:40 between Mexico and the United States (Rogers, 2002:5). In the US, the large remittance companies have cut their fees in response to the increased competition; in some areas (typically urban centres) Western Union now charges approximately $\$ 20$ for any transaction to Mexico from the United States under $\$ 1000$, less than 50 percent of what it charged in 1999 (See www.westernunion.com). In Canada, it is still very costly, at approximately $\$ 35$ per transfer under $\$ 1000$, and the remittance-sending market is dominated by one service provider: Western Union. This is not surprising since it is estimated that with over 100,000 locations, a new Western Union office opens every half an hour somewhere in the world (Rogers, 2002:5). For example, near Leamington, Ontario there are over 14 Western Union agents, nearly 10 of which are concentrated on the main streets where migrant workers shop on weekends.

Some small companies (such as FinMex) have begun providing wire transfer services in small town convenience stores throughout southern Ontario. FinMex representatives directly visit farms, since workers have limited access to transportation and there are so few FinMex locations. FinMex's agreement with Banamex (Citigroup) only permits transfers to their banks, which are not always accessible for workers' families living in remote areas of Mexico. Citigroup/Banamex requires customers to have a bank account with them and then charges \$7.00 USD to withdraw the money through a new program they are calling "WorldLink." Other service providers, such as Vigo Remittance Corporation and Lana Express (Global Funds Payment Solutions Inc.), have set up in Toronto, and they have begun expanding their 
services to reach migrant workers on remote Ontario farms. These companies have been rather aggressive in marketing to migrant workers. In fact, all of the workers interviewed in 2002 had received a marketing package from Lana Express/LanaFon, a company that provides remittance and long distance telephone services. The package was designed to look like an official government of Canada information kit, with a Canadian flag in the left corner and the phrase "Canada Welcome Kit. Bienvenidos a Canadá" next to it. When asked if they had received an official information package upon their arrival in Canada, fifteen workers indicated they had received the Lana Express package, believing the marketing package to be an official government communication.

Remittance sending represents a hidden cost within the temporary migration process, which can represent a significant loss to many migrants and their families and a notable profit for service providers. When money is sent home to families in Mexico, workers will typically call to inform family members of the amount being sent and the order number, as a way of ensuring security and peace of mind. All of the workers interviewed (25) indicated that they used a telephone to call home at least once a month in order to organize remittance sending and receiving, and to "keep in touch." Typically, migrants purchase telephone cards (e.g., Mundo) to make international calls either from pay phones off farm property (often many kilometers away by bicycle on dangerous country roads) or from "barn phones" on farm residences, accessed with employer permission for outgoing calls. Since the guidelines of the SAWP have no provisions for access to communication, workers typically cannot receive calls from Mexico or provide their families with a contact number while they are in Canada. On average, a $\$ 10-\$ 15$ phone card will provide approximately 200 minutes of call time to Mexico. It is not surprising that sales among telephone card service providers in North America have grown massively in the last 5 years (Comisión Federal de Telecomunicaciones [COFETEL], 2005; International Telecommunication Union [ITU], 2003).

\section{Conclusion}

The movement of workers through managed temporary foreign worker programs is not just a consequence of the movement of products globally, as Stalker (2000) contends, but directly related to globalization and global production itself. Globalization and the constituent emergence of a migration industry powered by developments in communication have played a direct role in facilitating the growth of contemporary temporary migration systems. Contemporary labour migration flows have been largely driven by transboundary labour markets (Gardezi, 1995); and they have been facilitated by expanding communication and transportation networks. Taking the SAWP as an exemplar of Harvey's (1990) time-space compression in action, it is clear that the 
way in which migrant workers engage in cross-border networks and exchanges benefits the agricultural sectors of core regions and the migration industry surrounding this migration network; the benefits to migrant workers and their families are not as clear, and must be evaluated with an eye to these costs. The costs of cross-border movements and ICTs necessary to temporary labour migration are absorbed by migrants alone, while many intermediaries profit from this movement. The work and costs shouldered by migrants and their families in this system remain largely unnoticed by researchers and policy makers. Temporary migration is often declared important for development or income-diversification in countries of origin; since migrant earnings are significantly diminished by the costs associated with temporary migration, it is not surprising that little sustainable development is emerging. Transnational costs put a considerable burden on migrants which must be factored into research on the role of remittances in development. From the preceding analysis, it is clear that both international remittance sending and telephone calling are integral, yet constrained, practices of transnationalism within a temporary migration system. Better access to communications technologies and lower costs for services would provide seasonal migrants with greater spatial and temporal control, and greater control over their transnational lives. As Castells (1996) contends, having the ability to control one's own movement is important to one's positioning within global power relations. It is also clear from this research that the perpetuation of this temporary migration system is driven by many more economic interests than those of the employer.

This research provides evidence of the formation of a "migration industry" around the SAWP, consisting of recruitment organizations, communication and transportation service providers, and other intermediaries. In Canada, around the SAWP, intermediaries directly and indirectly tied into the program profit or benefit significantly from this captive market: Foreign Agricultural Resource Management Services (FARMS), CanAg Travel, Royal Bank of Canada, Western Union, phone card companies such as GoodCall and VIGO, and local businesses serving migrants' needs, among others. Banks and other remittance transfer services, and telephone companies and long-distance service providers also hone in on the migrant market. Little competition, and the restrictions imposed by SAWP agreements, give a few companies a monopoly on the migrant worker market. This market is more than merely "captive" in some respects, since SAWP migrant workers are required to use CanAg Travel, and to pay the Royal Bank of Canada for life insurance, etc. Meanwhile, FARMS recovers migrant labour management costs from employers, and employers reclaim the majority of these costs from workers' paycheques, while also profiting from the migrant labour. Other intermediaries, who offer to "assist" workers in gaining entry to the program, and third-party agents who offer recruitment and mediating services to employers, are also part of this growing migration industry which stands to gain significantly from expanding temporary migration.

The Mexican-Canadian SAWP, and likely other temporary migration systems, are inherently transnational, and recursively related to globalization - stimulated and 
perpetuated through globalization and an emerging "migration industry" powered by new ICTs. Migrant workers are more than merely the "unseen side effect of free trade" (Klein, 2002:165). Indeed, migrant labour is now integral to the organization of global capitalism; migrant workers and their families engage in temporary production relations that are an increasingly vital component of local and international economies. Nonetheless, second generation labour migration programs continue to render the migrant worker vulnerable, temporary, and tertiary; providing a captive market for an expanding migration industry comprising third-party recruiters, communication and transportation service providers, and other private intermediaries. For Mexican seasonal agricultural migrants, it may be "Bienvenidos a Canadá," but their return flight home has already been booked.

\section{Acknowledgements}

I would like to thank Dr. Roderic Beaujot for all his valuable comments and support while working on this research. Part of this research was carried out with financial support from Wilfrid Laurier University and from the International Development Research Centre (IDRC).

\section{References}

Aceytuno, J. and D. Greenhill 1999. Managed migration and the Seasonal Agricultural Workers Program. Working Paper, Research on Immigration and Integration in the Metropolis.

Alarcón, R. 2000. Hometown associations and money remittances to Mexico. The developmental role of remittances in U.S. Latino communities and in Latin American countries. El Colegio de la Frontera Norte: Inter-American Dialogue Paper Series.

Alarcón, R. and R. Hinojosa-Ojeda. 1998. El uso de mecanismos para la transferencia de remesas monetarias entre migrantes Zacatecanos en Los Ángeles. UCLA NAID Center Working Paper, 8.

Bartelson, J. 2000. “Three concepts of globalization.” International Sociology 15(2):180-196.

Basok, T. 2003. "Mexican seasonal migration to Canada and development: A community-based comparison." International Migration 41(2):3-25.

Binford, L. 2002. "Social and economic contradictions of rural migrant contract labor between Tlaxcala, Mexico, and Canada." Culture and Agriculture 24(2):1-19.

Boyd, M. and E. Greico. 1998. Women and migration: Incorporating gender into international migration theory. Working Paper Series, Center for the Study of Population, Florida State University 35(3):98-139.

Castles, S. and M.J. Miller. 2003. The Age of Migration. London: Macmillan.

Castells, M. 1996. The Rise of The Network Society. Cambridge, MA: Blackwell Publishers.

Citizenship and Immigration Canada (CIC). 2007a. Facts and Figures 2006: Immigration Overview Permanent and Temporary Residents. Ottawa: Government of Canada. 2007b. Canada's new government makes improvements to the temporary foreign worker program. News Release, February 23. 
2005. The 2004 Foreign Worker Overview. The Monitor Winter 1-12.

Colby, C. 1997. From Oaxaca to Ontario: Mexican Contract Labor in Canada and the Impact at Home. Institute of Rural Studies. Davis, CA: California Institute of Rural Studies.

Comisión Federal de Telecomunicaciones (COFETEL). 2005.Telecommunications Market Statistics. www.cft.gob.mx. Government of Mexico.

El Programa de Trabajadores Agrícolas Temporales México-Canada (PTAT). 2007. Requested Estimates. Government of Mexico.

Fawcett, J. 1989. “Networks, linkages and migration systems.” International Migration Review 23(3):671680.

Fondation des entreprises en recrutement de la main-d'oeuvre agricole étrangère (FERME). 2007. Special Tabulations by Request. Québec.

Foreign Agricultural Resource Management Services (FARMS). 2007. FARMS Website.: http://www. farmsontario.ca/

2005. Employer Information Booklet. Mississauga, Ontario.

1995. The Quest for a Reliable Workforce: Reliable Workers, Regardless of Source (Mimeographed Report) Mississauga, Ontario.

Gardezi, H.N. 1995. The Political Economy of International Labour Migration. Montreal: Black Rose Books.

Griffith, D. 2004. "Challenges to farmworker organizing in the south: From the southern Tenant Farmers Union to the farm labor organizing committee's Mt. Olive campaign." Culture and Agriculture 26(1-2):22-35.

Harris, N. 1995. The New Untouchables: Immigration and the New World Worker. New York: IB Tauris \& Co Ltd.

Harvey, D. 1990. The Condition of Postmodernity. London: Blackwell.

Hawthorne, L. 2008. The Impact of Economic Selection Policy on Labour Market Outcomes for DegreeQualified Migrants in Canada and Australia. Montreal: Institute for Research on Public Policy. www.irpp.org

Held, D., Anthony G. McGrew, David Goldblatt, and Jonathan Perraton. 1999. Global Transformations: Politics, Economics and Culture. Stanford, CA: Stanford University Press.

International Telecommunication Union (ITU). 2003. World Telecommunication Development Report: Access Indicators for the Information Society. Online: http://www.itu.int/ITU-D/ict/publications/ wtdr 03/material/WTDR2003Sum e.pdf

Klein, N. 2002. Higher Fences at the Border: Migrant Workers Know that as Barriers to Trade Come Down, Barriers to People Go Up. Fences and Windows: Dispatches from the Front Lines of the Globalization Debate. Toronto: Vintage Canada.

Lowell, B. Lindsay. 2007. "Trend in international migration flows and stocks, 1975-2005.” Paris: OECD Social Employment and Migration Working Papers, No. 58.

Martin, P. and S. Martin. 2001. "Heavy traffic: International migration in an era of globalization." Brookings Review 19(4):41-44.

Massey, Douglas S., Joaquin Arango, Graeme Hugo, Ali Kouaouci, Adela Pellegrino, and J. Edward Taylor. 1993. "Theories of international migration: A review and appraisal." Population and Development Review 19(3):431-46. 
Massey, Douglas S., Joaquin Arango, Graeme Hugo, Ali Kouaouci, Adela Pellegrino, and J. Edward Taylor. 1998. Worlds in Motion: Understanding International Migration a the End of the Millenium. Oxford: Clarendon Press.

Organization for Economic Cooperation and Development (OECD). 2001. Trends in International Migration. Paris: OECD.

Orozco, M. 2003. Hometown Associations and their Present and Future Partnerships: New Development Opportunities? Report commissioned by USAID, September.

Parreñas, S.R. 2001. Servants of Globalization: Women, Migration, and Domestic Work. Stanford, CA: Stanford Press.

Portes, A. 1998. Globalisation from below: The rise of transnational communities. Working Paper Series, Transnational Communities Program, WPTC-98-01. Previously published in Smith and Korczenwicz, Latin America in the World Economy (pp.151-168). Westport, CT: Greenwood Press.

Preibisch, K. 2007a. "Local produce, foreign labor: Labor mobility programs and global trade competitiveness in Canada." Rural Sociology 72(3):418-449.

2007b. "Globalizing work, globalizing citizenship: Community-migrant worker alliances in southwestern Ontario.” Pp. 97-128 in L. Goldring and S. Krishnamurti (Eds.), Organizing the Transnational: Labour, Politics, and Social Change. Toronto: University of Toronto Press.

Rogers, A. (Ed.). 2002. "Competition in US-Mexico money transfer market." Traces 18: 3-5. Online: http://www.transcomm.ox.ac.uk/traces.htm

Ruddick, E. 2000. Canadian Immigration Data: "Administrative Data" on Permanent and Temporary Residents. Paper presented at Rethinking the Line, Preconference Workshop (October 22). Online Research and Statistics, Citizenship and Immigration Canada: http://www.cic.gc.ca/english/research/papers/cbds.html.

Sharma, N. 2001. "On being not Canadian: The social organization of "migrant workers' in Canada." Canadian Review of Sociology and Anthropology 38(4):415-440.

Smart, J. 1997. "Borrowed men on borrowed time: Globalization, labour migration and local economies in Alberta." Canadian Journal of Regional Science XX $(1,2): 141-156$.

Stalker, P. 2000. Workers without Frontiers: The Impact of Globalization on International Migration. Geneva: International Labour Organization (ILO), Geneva and Lynne Rienner Publishers.

Suro, R. 2003. "Latino remittances swell despite US economic slump migration information source." Migration Information Source, Migration Policy Institute. http://www.migrationinformation.org/ USFocus/display.cfm?ID=89

Therborn, G. 2000. "Globalizations: Dimensions, historical waves, regional effects, normative governance.” International Sociology 15(2):151-179.

Urry, J. 2000. “Mobile sociology.” British Journal of Sociology 51:185-203.

Vertovec, S. 2004. “Cheap calls: The social glue of migrant transnationalism.” Global Networks 4(2):219224.

Zlotnik, H. 1998. The Dimensions of International Migration: International Migration Levels, Trends and What Existing Data Systems Reveal. Technical Symposium on International Migration and Development. The Hague. 